\title{
23. Memory, technology and discourse in Fahrenheit 451
}

Oğuzhan KALKAN ${ }^{1}$

APA: Kalkan, 0. (2021) Memory, technology and discourse in Fahrenheit 451. RumeliDE Dil ve Edebiyat Araştırmaları Dergisi, (Ö9), 276-283. DOI: 10.29000/rumelide.984766.

\begin{abstract}
Memory is a way of connecting people with their pasts. Historical buildings, museums, archives and monuments are some of the tools which help people to remember their pasts (Nora, 1989). Books also help people to have a perspective about their communal past. However, these things lose their meaning in a dystopian society like the one portrayed in Fahrenheit 451. Memories turn into weapons that destruct and threaten human happiness and the foundations of society. For this reason, they are discarded from the foundations of the dystopic society. Furthermore, as Assmann (1989) notes, memory can become a tool of resistance under oppression. Thus, the totalitarian state uses technology to mesmerize people. By sinking into the hypnotic world of technology, people become passive subjects who pose no serious threats to the regime's sovereignty. However, in Bradbury's novel, the people who hold to books represent that there is still hope even for a fissure of twilight memories (Huyssen, 1995). This paper will investigate the relationship between books, technology and the discourse of the state in Fahrenheit 451 in order to understand the possible nature of memory in a dystopian world.
\end{abstract}

Keywords: Memory, technology, books, discourse

\section{Fahrenheit 451'de bellek, teknoloji ve söylem}

Öz

Bellek, insanları geçmişleriyle buluşturmanın bir yoludur. Tarihi binalar, müzeler, arşivler ve anıtlar, insanların geçmişlerini hatırlamalarına yardımcı olan araçlardan bazılarıdır (Nora, 1989). Aynı şekilde kitaplarda insanların ortak geçmişleri hakkında bir bakış açısına sahip olmalarına yardımcı olur. Ancak bunlar, Fahrenheit 451'de anlatıldığı gibi distopik bir toplumda anlamını yitirir. Anılar, insan mutluluğunu ve toplumun temellerini yok eden ve tehdit eden silahlara dönüşür. Bu sebeple, anılar distopik bir toplumun temellerinde yer almazlar. Dahası, Assmann'ın (1989) belirttiği gibi, hafiza baskı altında bir direniş aracı haline gelebilir. Buna karşı totaliter devlet, insanları uyuşturmak için teknolojiyi kullanır. Teknolojinin hipnotik dünyasına gömülen insanlar, rejimin egemenliğine ciddi bir tehdit oluşturmayan pasif özneler haline gelir. Fakat, Bradbury'nin romanında kitaplara bağlı kalan insanlar, alacakaranlık anılarının çatlaması için bile hala umut olduğunu ifade etmektedir (Huyssen, 1995). Bu makale, distopik bir dünyada belleğin olası doğasını anlamak için Fahrenheit 451'de kitaplar, teknoloji ve devlet söylemi arasındaki ilişkiyi araştıracaktır.

Anahtar kelimeler: Bellek, teknoloji, kitaplar, söylem

1 Dr. Öğr. Gör., Afyon Kocatepe Üniversitesi, Yabancı Diller Yüksekokulu, Mütercim Tercümanlık Bölümü, (Afyankarahisar, Türkiye), oguzkalkan@gmail.com, ORCID ID: 0000-0001-8298-8179, [Araştırma makalesi, Makale kayıt tarihi: 26.07.2021kabul tarihi: 20.08.2021; DOI: 10.29000/rumelide.984766]

Adres

RumeliDE Dil ve Edebiyat Araştırmaları Dergisi Osmanağa Mahallesi, Mürver Çiçeği Sokak, No:14/8 Kadıköy - ISTANBUL / TÜRKIYE 34714 e-posta: editor@rumelide.com tel: +90 $5057958124,+902167730616$
Address

RumeliDE Journal of Language and Literature Studies

Osmanağa Mahallesi, Mürver Çiçeği Sokak, No:14/8

Kadıköy - ISTANBUL / TURKEY 34714

e-mail: editor@rumelide.com

phone: +90 505 7958124, +90 2167730616 


\section{Introduction}

Memory is a tool to connect people with their pasts. By combining their pasts and their current states, people realize themselves and gather a whole identity. Tim Woods and Peter Middleton assert that "[m]emory is a means of overcoming the limitations of the human condition as it is understood in contemporary culture, by making the past appear once again in the present, despite its temporal, and possibly spatial, distance." (2000, p.2). Mental and physical conditions may hinder people from reaching the past but memory, free from the boundaries of time and space, may ignite the reminisces of the past any time and anywhere. As Proust explains in his memoirs, even a small object like the crumbs of a madeleine may take the person to their childhood (2006). Besides such small objects and incidents, some entities acquire a symbolic meaning in time to connect people with their pasts. Museums, monuments, artefacts and such communal objects become vessels to connect people with their pasts. Pierre Nora offers the term "lieux de memoire" (sites of memory) to describe any significant entity that is assigned with the duty of reminding people about their pasts. He explains the terms as: "a lieu de mémoire is any significant entity, whether material or non-material in nature, which by dint of human will or the work of time has become a symbolic element of the memorial heritage of any community" (1989, p. 17). Everything around can be a site of memory however, in a totalitarian regime, it is difficult to protect such objects. As Verovšek notes, "[i]n the totalitarian state, memory is not only unnecessary; it is a threat to its very structure" (2014, p. 399). For this reason, everything which gives information or reminds the past is confiscated. Language which is a powerful weapon of discourse is altered and shaped according to the needs of totalitarian state. Hence, it is difficult to preserve a sense of identity and continuity (Halbwachs, 1992).

In Ray Bradbury's Fahrenheit 451, it is books that threaten the dynamics of society because they have the power to connect people with their cultural heritage and they lead people to question everything happening around them. The regime bans books to establish an anti-discursive environment and uses technology as an antidote of books to keep people busy and numb. Buying new television screens and consumption become the goal of people and the programmes on it distract people from questioning their lives.

This paper attempts to evaluate the possible nature of memory in a dystopian society in relation to technology and discourse. The content and meaning of these terms will be inspected through a close reading of the novel in order to understand how memory and language becomes a weapon in the hands of an authoritarian regime.

\section{Memory and the State}

Halbwachs argues that "no memory is possible outside frameworks used by people living in society to determine and retrieve their recollections" (1992, p. 47). Furthermore, as Aleida Assmann notes, personal memories have a social quality and are constructed interactively but devoid of these features, they turn into "isolated scenes without temporal or spatial continuity" (in Tilmans et.al, 2010, p. 41). In Fahrenheit 451, life is engineered by the state itself. Everything reminding the past is disturbed and intervened with tools of technology and no space is left even for thinking. People live the life administered to them. They have no knowledge or idea about the things which may distract them from the imposed standards. They do not even look down to earth to see natural phenomena such as the dew on the grass or look up to the moon to see the silhouette on it. They live the life broadcasted on television screens. They cannot define their feelings when they come across such events:

"Bet I know something else you don't. There's dew on the grass in the morning."

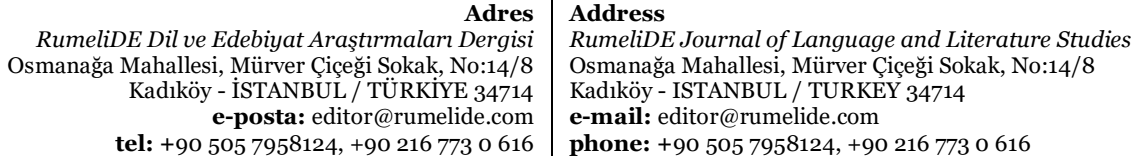


He suddenly couldn't remember if he had known this or not, and it made him quite irritable.

"And if you look"-she nodded at the sky-"there's a man in the moon." He hadn't looked for a long time. (Bradbury, 2008, p. 16)

People cannot define their feelings in such a dystopic world. They are baffled when they are presented with something which is out of their mechanical routine. They do not know how to react to such things because they do not share any social time with other people. The only simple discussion topic among individuals revolves around a television programme. In this dystopic world, the state controls diseases and has solutions even for melancholy. By injecting some medicine or just simply by changing blood, the person is regenerated and reprogrammed. They continue their standard routines as if nothing happened. However, the memories of the past are also gone with this renewal.

The protagonist of the novel Guy Montag lives the life tailored for him. He is a promising fireman who burns books rather than putting out fires. In a technologically advanced dystopian society where houses are made fireproof, firemen are assigned the duty of burning books to prevent people from reading them. His life changes when he meets a young girl named Clarisse on the way home. She is different from the usual people Montag encounters in his life. She is a lively and warm-blooded person. She leads him to ask questions about life. Despite the artificial and mechanic life in other households, Montag could see and hear the laughter and congeniality swarming in Clarisse's house:

\begin{abstract}
Laughter blew across the moon-colored lawn from the house of Clarisse and her father and mother and the uncle who smiled so quietly and so earnestly. Above all, their laughter was relaxed and hearty and not forced in any way, coming from the house that was so brightly lit this late at night while all the other houses were kept to themselves in darkness. (Bradbury, 2008, p. 26)
\end{abstract}

The things he could see from his window are very unusual for Montag because he is not used to people who can freely express themselves. The citizens of this dystopic world have no control over their lives. They live in the darkness and the things they can talk about are limited to a few subjects like the television shows. They do not have any freedom to talk about other things because the language and its mediator, books, are confiscated by the totalitarian system. As Booker notes,

The governments described in dystopian literature tend to focus their energies on language not only because it is a potentially powerful tool with which to control and manipulate their subjects but also because language may harbor powerfully subversive energies that such governments would like to suppress. (qtd.in Wien, 2012, p.31)

In such an artificial world devoid of any kind of social interaction, it is impossible to think of jokes. People need joke machines to cheer them up. They live in an abstract world. They do not have anything concrete to hold onto or to attribute their memories. For this reason, museums are all made up of abstract things and there is nothing called photography:

\begin{abstract}
"No, not anything. They name a lot of cars or clothes or swimming-pools mostly and say how swell! But they all say the same things and nobody says anything different from anyone else. And most of the time in the cafes they have the joke-boxes on and the same jokes most of the time, or the musical wall lit and all the colored patterns running up and down, but it's only color and all abstract. And at the museums, have you ever been? All abstract. That's all there is now. My uncle says it was different once. A long time back sometimes pictures said things or even showed people." (Bradbury, 2008, p. 43)
\end{abstract}

The tendency for abstract art blocks the path of photography as a reflective art. As Susan Sontag illustrates in her book On Photography (2001), the roots of this art go back to ancient times. As in Plato's cave allegory, people only see the reflection of real things on the walls of the cave. From this perspective, photography

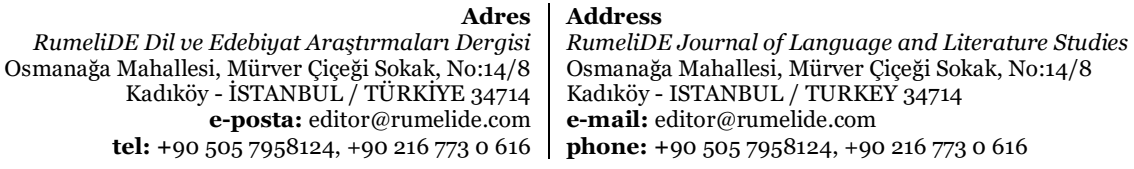


enables people to come across a moment from the past in a delayed and indirect manner. For its qualities, photography can be paralleled to history and memory. As Kracauer argues, photography "makes it easier for us to incorporate the transient phenomena of the outer world, thereby redeeming them from the oblivion" (1969, p. 192). As a visual art, photography is an attempt to deliver a moment from the past however it cannot survive in a setting where everything reminding the past is banned. Even the language, which is a reflection of the culture, is altered in this dystopian society. A colloquial expression such as "once upon a time" is not authorized to stay in people's repertory:

Montag hesitated, "Was-was it always like this? The firehouse, our work? I mean, well, once upon a time..." "Once upon a time!" Beatty said. "What kind of talk is that?" Fool, thought Montag to himself, you'll give it away. At the last fire, a book of fairy tales, he'd glanced at a single line. "I mean," he said, "in the old days, before homes were completely fireproofed" (Bradbury, 2008, p. 47)

The language and the customs are tailored according to the needs of the dystopian state. As in George Orwell's 1984, history is also perverted according to the needs of the order. Benjamin Franklin who founded the first fire brigade to extinguish the fires in the colonies is depicted as the first fireman who put on fires.

People are numbed with the programmes on television. They cannot have time to think about anything. There is a bombardment of advertisements even on subways in this anti-discursive environment to fill the empty slots in people's lives. They encourage people to buy things in order to create a consumerist society. People are so mesmerized in such a controlled life that they do not even remember important dates such as their first date which was only ten years ago:

"When did we meet. And where?"

"When did we meet for what?" she asked.

"I mean-originally."

He knew she must be frowning in the dark.

He clarified it. "The first time we ever met, where was it, and when?"

"Why, it was at --"

She stopped.

"I don't know," she said.

He was cold. "Can't you remember?"

"It's been so long."

“Only ten years, that's all, only ten!”

"Don't get excited, I'm trying to think." She laughed an odd little laugh that went up and up. "Funny, how funny, not to remember where or when you met your husband or wife." (Bradbury, 2008, pp. 57-58)

The first time when you meet your future partner is an important date but thinking about the past is not allowed in such a dystopian state. Neither Montag nor his wife can remember the date under the oppression of the state. This situation becomes more bitter when he envisions a possible death of his wife after taking a couple of drugs:

And he remembered thinking then that if she died, he was certain he wouldn't cry. For it would be the dying of an unknown, a street face, a newspaper image, and it was suddenly so very wrong that he had begun to cry, not at death but at the thought of not crying at death, a silly empty man near a silly empty woman, while the hungry snake made her still more empty.

How do you get so empty? he wondered. Who takes it out of you? (Bradbury, 2008, p. 59)

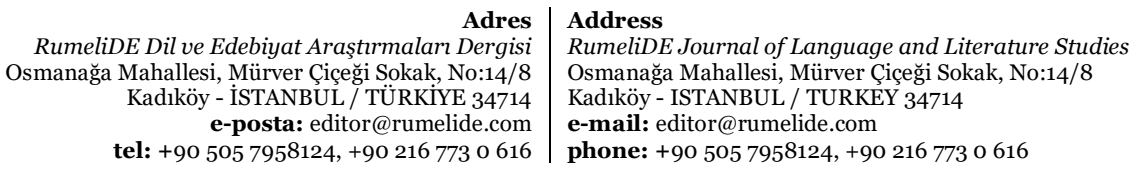


The system creates senseless, numbed people. Despite the mediocrity of life, his neighbour Clarisse kindles a desire to question the world around him. He gets interested in books and starts to understand they have an identity and a character which attract people. He explains this situation to his wife as:

"You weren't there, you didn't see," he said. "There must be something in books, things we can't imagine, to make a woman stay in a burning house; there must be something there. You don't stay for nothing."

$[\ldots]$

And for the first time I realized that a man was behind each one of the books. A man had to think them up. A man had to take a long time to put them down on paper. And I'd never even thought that thought before. (Bradbury, 2008, p. 68)

Montag is shocked when he sees a woman who does not leave her books when they are being burned. This situation affects him deeply. He understands that each book has its own personality. He realizes that it takes a long time to write a book, but as a fireman, he burns them in a few minutes.

Montag also wants his wife to think and question the things going around but she rejects it. As an ordinary citizen, she rejects to be bothered about the important matters of life:

"Let me alone," said Mildred. "I didn't do anything." "Let you alone! That's all very well, but how can I leave myself alone? We need not to be let alone. We need to be really bothered once in a while. How long is it since you were really bothered? About something important, about something real?" (Bradbury, 2008, p. 69)

People are so conditioned that they do not want to be bothered about anything. They have a selfish lifestyle. Montag's boss, Beatty stands as the spokesperson of the system and mentions the reluctance of people against literature and their tendency for lighter and shorter forms of art:

"Classics cut to fit fifteen-minute radio shows, then cut again to fill a two-minute book column, winding up at last as a ten- or twelve-line dictionary resume. I exaggerate, of course. The dictionaries were for reference. But many were those whose sole knowledge of Hamlet (you know the title certainly, Montag; it is probably only a faint rumor of a title to you, Mrs. Montag) whose sole knowledge, as I say, of Hamlet was a one-page digest in a book that claimed: now at least you can read all the classics; keep up with your neighbors. Do you see? Out of the nursery into the college and back to the nursery; there's your intellectual pattern for the past five centuries or more." (Bradbury, 2008, p. 72)

Through Beatty, Bradbury harshly criticizes the lifestyle of modern societies which ignores art and culture for the sake of technology. He argues that all the education you get becomes unnecessary in this cyclical life form. Thus, time - and history as a result - loses its importance because it contains no intellectual activity. In this mechanical, robotic lifestyle, there is no need to question anything. Life and pleasures are condensed to simple things such as pressing buttons or fitting nuts. Duties that require thinking are eliminated:

"School is shortened, discipline relaxed, philosophies, histories, languages dropped, English and spelling gradually neglected, finally almost completely ignored. Life is immediate, the job counts, pleasure lies all about after work. Why learn anything save pressing buttons, pulling switches, fitting nuts and bolts?"(Bradbury, 2008, p. 73)

In such an atmosphere, it is impossible to talk about intellectuality. Through technology, the state eliminates everything which may lead people to think. Even reading is degraded to pictures in comic books. This situation is a result of the choices of the public in order to be happy and not be bothered. In the same manner, the state saw books as a weapon which threatens the uniformity of society and started to destroy them. In this process, the duty of the fire brigade changed from putting out fires to burning books. By this way, the state could fight against any kind of discursive attempts which aim to overthrow it and "stand

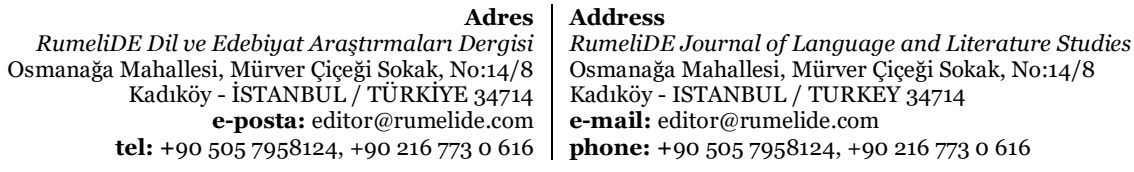


against the small tide of those who want to make everyone unhappy with conflicting theory and thought" (Bradbury, 2008, p. 81). Thus, the fire brigade became the protector of the sovereignty of the state rather than protecting the households of citizens and by burning books, it eliminated the possible dangers of discord between the intellectual and ignorant people.

After reading the books, Montag starts to feel uneasy. He understands that they cannot accommodate in society as a family. However, it is difficult for his wife, Millie, to adjust to this new situation. He tries to convince her about books: "Maybe the books can get us half out of the cave. They just might stop us from making the same damn insane mistakes! I don't hear those idiot bastards in your parlor talking about it" (Bradbury, 2008, p. 96). Montag wants his wife to have a look at books but she does not share the same ideas as her husband. She is a stereotype of the society who watches the television programmes numbly and chats about them to her neighbours. As in Plato's cave allegory, she is content with the artificial shadows of real life reflected on her television screens. As an obedient citizen, she abandons her husband in such a dangerous situation and tips the fire brigade about the books in their house.

Faber, a retired professor, stands for the common sense of the old world and guides Montag through his journey. He offers meaning behind factual things. There is nothing much he can do to change the oppressive system because everything he owns as a retired professor is taken from him. He relates Montag about good and bad writers, and why books are threats to society:

The good writers touch life often. The mediocre ones run a quick hand over her. The bad ones rape her and leave her for the flies.

"So now do you see why books are hated and feared? They show the pores in the face of life. The comfortable people want only wax moon faces, poreless, hairless, expressionless." (Bradbury, 2008, p. 108)

Faber explains that books disturb people with the harsh realities of life whereas television screens only show perfect and light side of life. Captain Beatty is also aware of the heavy content of books. He warns Montag that books turn into dangerous tools in the hands of an uneducated mind:

Give a man a few lines of verse and he thinks he's the Lord of all Creation. You think you can walk on water with your books. Well, the world can get by just fine without them. Look where they got you, in slime up to your lip. If I stir the slime with my little finger, you'll drown! (Bradbury, 2008, p. 152)

Captain Beatty explains that books provide an ecstasy for an unaccustomed mind. He thinks that the world can survive without books as in the prehistoric ages. The television screens which cover the walls of rooms numb people and the programmes on television become artificial families of the society. By this way, they keep the people's minds busy and let them think that life is eternal.

There is no solution or turning back in this system. However, the book people, who are the outlaws, hope to ignite the prospect of intellectual survival by memorizing books. They recite the books in their memories to whoever wants to hear them. They are walking books that pose no threat to society because they do not carry any illegal items. They try to survive by passing the books in their memories to next generations: "All we want to do is keep the knowledge we think we will need, intact and safe. We're not out to incite or anger anyone yet. For if we are destroyed, the knowledge is dead, perhaps for good" (Bradbury, 2008, p. 195). They prefer a passive method for their survival. They know that they have an important purpose in life and with their memory faculty they think that they will construct the society again.

We're going to meet a lot of lonely people in the next week and the next month and the next year. And when they ask us what we're doing, you can say, We're remembering. That's where we'll win out in the

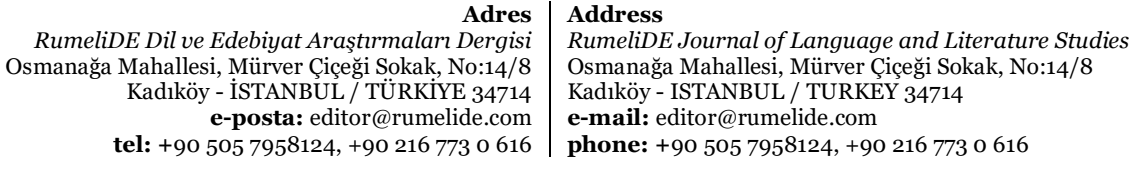


long run. And some day we'll remember so much that we'll build the biggest goddam steam-shovel in history and dig the biggest grave of all time and shove war in and cover it up. (Bradbury, 2008, p. 209)

They prefer a pacifist method to rebuild the world. They rely on the books in their memories to overcome the diseases of modern societies such as wars.

By the end of his journey, Montag understands the meaninglessness of his life. His transformation starts and as an outlaw, freed from the boundaries of the state, he starts to think about his past. Nothing distracts him and remembers the date when he first met his wife. The distractive loop of advertisements does not distract him anymore. He remembers the section from Holy Bible which he read on the subway. His regeneration begins and feels "the slow stir of words, the slow simmer" (Bradbury, 2008, p. 210).

\section{Conclusion}

Memory is a distinctive feature of humankind. As Nietzsche argues, the human being is a remembering animal who "braces himself against the great and even greater pressure of what is past: it pushes him down or bends him sideways, it encumbers his steps as a dark, invisible burden" (1997, p. 61). However, for other kinds of species, "every moment really dies, sinks back into night and fog and is extinguished for ever" (1997, p. 61). In his novel, Bradbury assigns an important duty of remembering to the members of modern society. Without remembering, people are numbed and lose the connection with the past, the present and the future. Thus, memory becomes a "temporal component of identity" (Ricoeur, 2009, p. 81). In dystopian fiction, authoritarian regimes aim to terminate the connections between these dimensions of time and attempt to create their own alternative realities. In this process, language becomes an important weapon to resist oppression and as Sisk argues in Transformations of Language in Modern Dystopias, "the struggle for mastery of the world boils down to mastery over the word" (1997, p. 180). Aware of these realities in a post World War II atmosphere, Bradbury still holds to his hopes about the survival of humankind through holding to memories and books, but he also warns about the possible dangers of technology:

machines themselves are empty gloves. And the hand that fills them can be good or evil. Today we stand on the rim of space, and man, in his immense tidal motion, is about to flow out toward far new worlds but he must conquer the seed of his own self-destruction. Man is half-idealist, half-destroyer, and the real and terrible fear is that he can still destroy himself before reaching for the stars. I see man's selfdestructive half, the blind spider fiddling in the venomous dark, dreaming mushroom-cloud dreams. Death solves all, it whispers, shaking a handful of atoms like a necklace of dark beads. (qtd. in Nolan, 1963, p. 8)

Bradbury and writers of the cold war era such as George Orwell and Aldous Huxley are just about their projections of a catastrophic world. Their warnings about a chaotic world are still valid for the modern world. They emphasize that memory and language are important weapons to fight against the discourse of the dystopian state and the tools of technology which numb and direct people towards wars. As Bloom notes in an introduction to Bradbury's novel: "If you cannot read Shakespeare and his peers, then you will forfeit memory, and if you cannot remember, then you will not be able to think" $(2008$, p. 2). This reciprocal relationship between language and memory explored in dystopian fiction may become a prospective area for further studies in different fields such as sociology, psychology, history, cultural studies and literature.

\section{Bibliography}

Bloom, H. (2008). Bloom's Modern Critical Interpretations Ray Bradbury's Fahrenheit 451. New York: Infobase. Bradbury, R. (2008). Fahrenheit 451, Harper Voyager, London.

Halbwachs, M. (1992). On Collective Memory, edt. by Lewis A. Coser. Chicago: The University of Chicago.

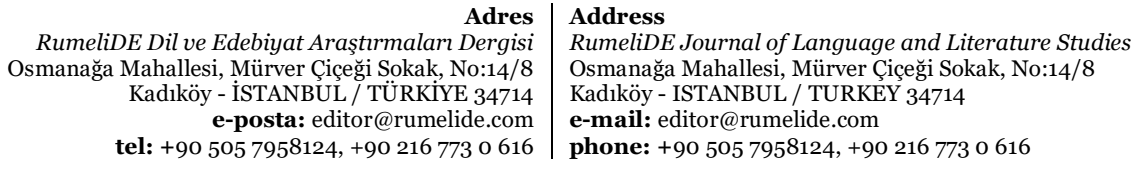


Kracauer, S. (1969). The Last Things Before the Last. Oxford University Press. New York.

Nietzsche, F. W. (1997). 'On the Uses and Disadvantages of History for Life' (Trans. R. J. Hollingdale), Untimely Meditations, edt. By Daniel Breazeale. Cambridge: Cambridge University Press.

Nolan, F. W. (1963, May). Bradbury: Prose Poet in the Age of Space, Fantasy and Science Fiction, 24, 8.

Nora, P. (1989). Between Memory and History: Les Lieux de Memoire, Representations, 26, 7-25.

Proust, M. (2006). Remembrance of Things Past (Trans. C. K. Scott Moncrieff). London: Wordsworth Editions.

Ricoeur, P. (2004). Memory, History, Forgetting. Chicago: The University of Chicago Press.

Sisk, D. W. (1997). Transformations of Language in Modern Dystopias. London: Greenwood Press

Sontag, S. (2001). On Photography. New York: Picador.

Tilmans, K., van Vree F., Winter, J. (eds.) (2010). Performing the Past: Memory, History and Identity in Modern Europe. Amsterdam: Amsterdam University Press.

Verovšek, P. J. (2014, Summer). Unexpected Support for European Integration: Memory, Rupture, and Totalitarianism in Arendt's Political Theory, The Review of Politics, 76,3, 389-413. Last Accessed, https://www.jstor.org/stable/43670988

Wien, H. (2012). Claiming Mastery of the Word. (Master's Thesis). Tromso: Universitetet Tromso. Last Accessed, https://munin. uit.no/bitstream/handle/10037/4848/thesis.pdf?sequence $=2$

RumeliDE Dil ve Edebiyat Araştırmaları Dergisi Osmanağa Mahallesi, Mürver Çiçeği Sokak, No:14/8 Kadıköy - İSTANBUL / TÜRKIYE 34714 e-posta: editor@rumelide.com tel: +90 $5057958124,+902167730616$
Address

RumeliDE Journal of Language and Literature Studies Osmanağa Mahallesi, Mürver Çiçeği Sokak, No:14/8

Kadıköy - ISTANBUL / TURKEY 34714

e-mail: editor@rumelide.com

phone: +90 505 7958124, +90 2167730616 